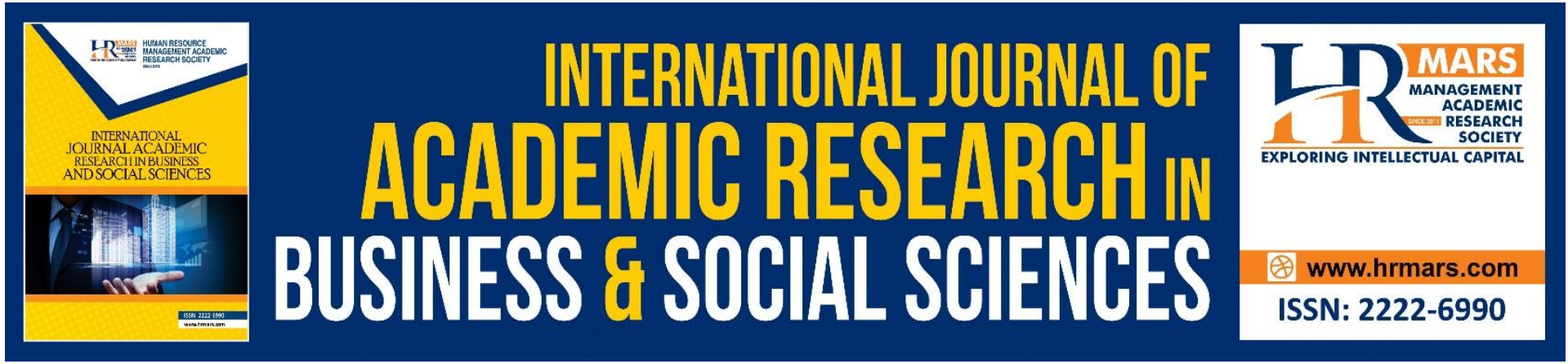

\title{
Political Participation Integrity Scale: Validity and Psychometric
}

Mohd Sufiean Hassan, Maizatul Haizan Mahbob, Zaliffah Abdul Wahab, Fazurah Mustaffa

To Link this Article: http://dx.doi.org/10.6007/IJARBSS/v11-i8/10360

DOI:10.6007/IJARBSS/v11-i8/10360

Received: 09 June 2021, Revised: 15 July 2021, Accepted: 06 August 2021

Published Online: 24 August 2021

In-Text Citation: (Hassan et al., 2021)

To Cite this Article: Hassan, M. S., Mahbob, M. H., Wahab, Z. A., \& Mustaffa, F. (2021). Political Participation Integrity Scale: Validity and Psychometric. International Journal of Academic Research in Business and Social Sciences, 11(8), 1498-1513.

Copyright: (C) 2021 The Author(s)

Published by Human Resource Management Academic Research Society (www.hrmars.com)

This article is published under the Creative Commons Attribution (CC BY 4.0) license. Anyone may reproduce, distribute, translate and create derivative works of this article (for both commercial and non-commercial purposes), subject to full attribution to the original publication and authors. The full terms of this license may be seen

at: http://creativecommons.org/licences/by/4.0/legalcode

Vol. 11, No. 8, 2021, Pg. $1498-1513$

Full Terms \& Conditions of access and use can be found at http://hrmars.com/index.php/pages/detail/publication-ethics 


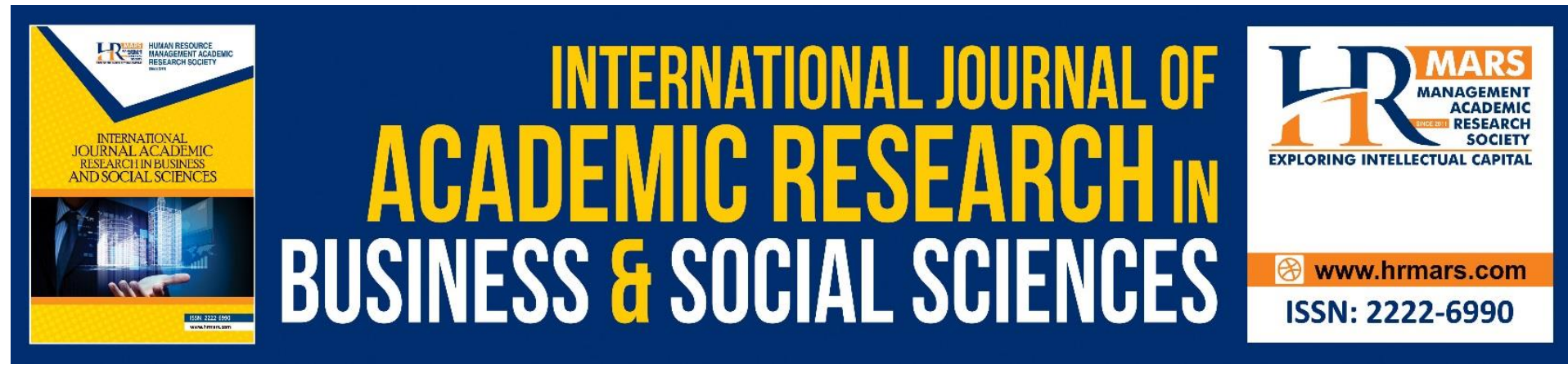

\title{
Political Participation Integrity Scale: Validity and Psychometric
}

\author{
Mohd Sufiean Hassan ${ }^{1}$, Maizatul Haizan Mahbob², Zaliffah \\ Abdul Wahab ${ }^{3}$, Fazurah Mustaffa ${ }^{4}$ \\ ${ }^{1}$ Universiti Teknologi MARA, Melaka Branch, Malaysia, ${ }^{2}$ Universiti Kebangsaan Malaysia, \\ ${ }^{3}$ Universiti Teknologi MARA, Shah Alam, Malaysia, ${ }^{4}$ Kolej Universiti Islam Melaka
}

\begin{abstract}
The integrity of political participation is a practice that should exist in a democratic environment like Malaysia. However, empirical studies on political participation integrity are less concerned by social sciences and humanities scholars. Therefore, this study focuses on examined the psychometric scale of the political participation integrity among young people. An adapted scale of the political participation integrity was tested on 388 students in Melaka state from four higher education institutions, namely Universiti Teknologi MARA (UiTM), Universiti Teknikal Malaysia, Melaka, Universiti Multimedia (MMU) Melaka and Kolej Universiti Islam Melaka (KUIM) by simple random sampling. The scale of the integrity of political participation Instrument was integrated from a combination of Social Media Usage and Online Political Participation Scale and Integrity Scale to test the value of young people's integrity through confirmatory factor analysis (CFA). Results show that the multi-dimensional model of political participation integrity has achieved goodness-of-fit and achieved convergent validity based on the significant relationship of each variable. This scale also reached discriminant validity and predictive validity that supports the psychometric characteristics of the Malay version. This study directly contributes to forming the integrity of the political participation scale that previous researchers have overlooked.
\end{abstract}

Keywords: Integrity, Political Participation, Media-Savvy, Authentic Sources, Moral Creation, Ethical Actions

\section{Introduction}

Politeness and integrity practise of political participation are poorly practised among young people on social media. If we look at the situation of the use of social media in Malaysia, especially those related to political participation, it shows a low level of integrity. Nevertheless, it is essential to study and validate young people's actual level of integrity in social media, especially those related to political participation. There is no specific social media model with integrity, so the researcher chose to conduct this study.

Most young people are adept at using new media. This medium serves as a conduit for sharing information, communicating, and so on. On the other hand, young people are commonly associated with irresponsible use of social media, particularly concerning political problems. Therefore, it is vital to study whether media literacy also helps influence the 
integrity practices of young people in social media. Media literacy requires not only the capacity to utilise the media but also the ability to locate and use media, the ability to assess and analyse communications, and the ability to create messages creatively while adhering to cultural values and conventions. The integrity of political participation in the use of social media has become a national issue that has received a lot of attention in the media. Therefore, the study to develop an integrity model of new media use is also expecting to benefit governments, policymakers, political parties, media practitioners and future researchers.

The use of social media with integrity means being responsible for the information disseminated and honest. In addition, consumers must follow all the rules set by the government. Its goal is to defend and respect the dignity and rights of others, regardless of their background, as well as to respect other people's property, health, and safety and protect the country's good name (University, 2014).

According to Lunnay et al (2015), the integrity of social media use means safeguarding the rights and personal information of individuals or other social media users. For instance, breaking the secrecy standard entails sharing confidential material supplied by a friend to various contacts on social media without that friend's knowledge (Herman, 2011). Herman also highlighted multiple characteristics that influence the integrity of social media use, including the context, offender, kind or type of content, and information transmission principles. It is important to emphasise that social media users must be aware of the information they receive and determine whether or not to share it.

In line with that, the integrity of the use of social media can be defined as adhering to moral values with total commitment to those values. In contrast, social media is a medium used as a place to interact, convey information and propaganda, advertising space, find old friends, exchange opinions, and as a learning vehicle and reference source. The advent of social media has opened up the world of communication more widely and saves time. However, according to Adnan (2015) in his study entitled The Role of Mass Media in Dignifying National Integrity, social media should be used best to preserve national integrity by all parties who love Malaysia. Otherwise, most likely, less responsible parties who do not have integrity use social media will abuse it.

Thus, in the community's enthusiasm to use social media as a necessity of life, there are also a handful of people who abuse it for personal gain, damage and bring down other individuals, commit cyber crimes and play on the security issues of the people and the country. Therefore, this act will have a negative impact, compromise personal integrity and is against the law.

Integrity in social media use implies that the community or users of social media utilise this medium sensibly by adhering to societal moral standards and norms and national regulations stated in the federal constitution. In addition, it means that the community knows the scope and limits in expressing and casting all views on social media.

Therefore, the purpose of this study is to measure the scale of integrity practices of young people's political participation in social media by considering four main elements, namely, 1) Media-savvy, 2) authentic sources, 3) moral creation and 4) ethical action. Finally, this study forms a scale measuring the integrity practices of social media political participation among young people. This scale of political participation integrity practises expected to be used not just by media practitioners but also by policymakers, legislators, and scholars who are directly concerned with political involvement, particularly among Malaysia's younger generation. 


\section{Political Participation of Young People in Social Media}

Previous research has found that young people's political impulses are channelled into various forms of political participation, such as traditional (offline) (Mohamad, 2018) or the internet (online) (Kahne \& Bowyer, 2018). However, this tendency is inconsistent, mainly traditional or offline political participation such as voting during elections (General Election or ByElection), campaigning and membership of political party organizations (Rogstad \& Vestel, 2011).

Razali et al (2016) backed this approach by defining conventional political participation as participation in political activities that become the norm or routine of a community, such as voting and campaigning on behalf of political parties during elections. Furthermore, Theocharis and Quintelier (2014) classify conventional political participation as wearing badges, vehicle mirror stickers of political parties, writing letters to politicians, and participating in community service activities or campaigns organised by political parties (Zhang \& Chia, 2006).

This conventional definition expanded its scope to unconventional (Eckstein et al., 2013), using media referring to demonstrations, street protests and public debates to aggressively influence government decisions (Marsh, 2008). In the context of unconventional political participation, previous researchers reported the function of the media as a platform for young people's political participation (Gil de Zúñiga et al., 2012). Social media developments such as Facebook (Gustafsson, 2012), news portals (Mohd Azizuddin, 2014), and Twitter (Bekafigo \& McBride, 2013) have been claimed to boost young people's political tendencies, resulting in a definition of online political participation

\section{The Role of Social Media And Political Participation Among Young People}

The media environment has changed drastically with the development of communication technologies that have shaped social media as a more effective communication platform than conventional media (Anduiza et al., 2012) (Anduiza et al., 2012). Its user-friendly features compared to traditional media positively return to political campaigns, especially the young (Gustafsson, 2012). By using social media, young people are presented with more flexible and effective participation in voicing their views and voices (Yoo \& Gil de Zuniga, 2014).

Furthermore, social media provides an effective information retrieval area (Kümpel et al., 2015) about political crises that is difficult to find through traditional media channels such as newspapers and television. With a single click, all information can be displayed on the screen in various angles and descriptions, from numerous sources, and across national borders in a short time (Shaheen, 2008).

The use and influence of this medium have shown that social media such as Facebook, Twitter, Blog and YouTube are changing how individuals find, retrieve and share news or information (Picone et al., 2016) compared to traditional media. Furthermore, the interactive features of social media allow users to share information with the virtual community quickly (Lee \& Ma, 2012). Protests in Syria, Egypt, Libya, and other Middle Eastern nations, for example, have spread via social media sites such as Twitter and Facebook. Furthermore, social media offers interactive audiovisuals that allow users to insert pictures and text, sound and video at once. Although the photos and videos taken produce low-quality images and sounds but are still acceptable by the virtual community (Lee \& Ma, 2012).

Most importantly, interactive social media features with participation, openness, community, and conversation allow users to provide a personalized view of a website (ChanOlmsted et al., 2013). Next, the user's friends or followers will comment from a personal 
perspective on the site and read by others. Indirectly, social media allows users to publish their opinions on specific issues without judging facts and validity (Lee \& Ma, 2012).

The study conducted by Mohd. Adnan et al (2012) that political news from social media has a significant relationship with political engagement among young people. Researchers discovered that social media has played and will continue to play an essential role in changing the Malaysian political landscape. Through an online survey of young Malaysian urban middle-class residents aged 21 to 40 living in the Klang Valley, especially when the mainstream media's reporting of news sources is not as transparent as it should be.

Dunne, Lawlor, and Rowley (2010), using a qualitative technique, discovered that young people regard internet news or information as a reputable source of information. These young individuals are also involved in the virtual community. With interactive and multimedia capabilities, social media has become a popular way for people to express and share their information and opinions actively.

\section{The Consequences of Political Participation Without Integrity of Young People on Social Media}

In 2011, over 770 million individuals globally used social media. According to Internet World Stats (2021), as of April 2021, Facebook users had reached 2,803,147,884 billion people globally. Malaysian Facebook users have surpassed 27 million. Social media has become a complement to the mass media, and it seems to be ingrained and becoming a part of the lives of young people. In addition, social media has now become the most popular medium among the community, especially the young, to establish relationships and interact between communities around the world. According to Subramaniam (2015), social media has shown significant growth, with nine of the top 20 Malaysian websites being social media sites. The top five websites in Malaysia are Yahoo, Facebook, Google, YouTube and Blogger. Social media usage is now ubiquitous, with most users being young people in this country (Leong, 2015).

This indicates that young people heavily engaged in social media in their daily activities (Muntaen, 2015). In general, news and information content on social media is more readily available than conventional media (Salman et al., 2011). In addition, the unrestrained flood of information and censorship makes social media a complete media for a democracy, where social media owners are free to voice opinions and debate until the content goes viral (Berger \& Milkman, 2012).

Uploading or sharing viral information is essential for young people to gain followers on social media. Unfortunately, young people unethically disseminate fake news, upload libellous and seditious statuses, and post material to provoke to be trendy. A study conducted by Al-Kandari \& Hasanen (2012) found that social media such as Facebook, Twitter, Instagram and Youtube is an effective tool to gain support. Simply sending a post mixed with slander, statistics or false facts and within seconds can double the number of supporters (Valenzuela, 2013).

In addition to sending wrong and false facts (Ferrari, 2018), the younger generation is also more daring to issue abusive words, swear, and insult the country's government system to perceive the country's leadership negatively. Such a reaction of young people is a normal response because young people have the community's characteristics that are the nature of advocacy, solidarity, activism, and easy to get support from each other (Febriansyah \& Ismail, 2013). However, it is against the culture of a society in Malaysia that maintains the values of 
manners, morals and ethics instilled in young people (Mohd Fauzi \& Mohd Khairul Naim, 2012).

The new political dynamics in Malaysia brought about by young people's participation via social media should not be disregarded. A study on social media and protest behaviour of young people conducted by Valenzuela, Arriagada, and Scherman (2012) discovered that social media mediums such as Facebook had a substantial and favourable link with protest activities. Active use of social media influences online political participation, leading to more aggressive offline political participation (Norris, 2000; Wellman \& Haase, 2001).

To address the problem of non -integrity use of social media, there needs to be a robust measure to explain the integrity of political participation. Therefore, if moral values lived and individuals have deep relationships with values and norms, they will consciously reduce their proclivity to conduct immoral acts (Schlenker et al., 2009).

This study adapts Yang \& DeHart (2016) social media usage scale and online political participation to the integrity dimensions of political engagement, considering cultural features in Malaysia and incorporating Schlenker's integrity scale (2008). A detailed description of the Political Participation Integrity Scale provided below.

\section{Methodology}

Students from four public and private universities were chosen at random. A total of 400 questionnaires were distributed, but only 388 were successfully returned with complete. This study uses self-answered questionnaires as a means of data collection. Based on the number of respondents ( $n=388$ ) with complete data in this study, this sample size is large enough to use SEM (Hair et al., 2014). Before proceeding to the final data collection, expert validity, pretests, and pilot studies to test the reliability of the instruments were conducted to ensure the consistency of the questionnaire. The Cronbach Alpha reliability coefficient for all four variables, exceeding 0.70, indicates good internal consistency (Hair et al., 2014).

\section{Research Instrument}

The questionnaire consists of two parts is used as a research instrument. Part A consists of general information on demographic variables, namely gender, age, status, race, education and use of social media. Part B contains the Political Participation Integrity scale adapted from the Social Media Use and Online Political Participation scale by Yang \& DeHart (2016) and the scale of integrity developed by Schlenker (2008) and translated into Malay. The scale for measuring integrity and political participation is a scale that has been established and proven to be reliable because it has been widely used in previous studies. The pilot test found that the reliability (Cronbach alpha) for all four dimensions of the political participation integrity scale - Media-savvy constructs, authentic sources, moral creation, and ethical action was between $0.82-0.84$. The use of well-established scales helps in terms of the scale's reliability in obtaining information through the public (Babbie, 2013). This scale contains 29 items and measured using a seven-level interval scale from 1 = strongly disagree to $7=$ strongly agree. This measurement scale measures media-savvy, authentic sources, moral creation, and ethical action 
Table 1 : Dimension of the Political Participation Integrity and Cronbach Alpha

\begin{tabular}{|c|c|c|c|}
\hline $\begin{array}{l}\text { Dimension of } \\
\text { the Political } \\
\text { Participation } \\
\text { Integrity }\end{array}$ & Research Instrument & Operasional Definition & $\begin{array}{l}\text { Cronbach } \\
\text { Alpha }\end{array}$ \\
\hline Media-Savvy & $\begin{array}{l}\text { The Social Media Use } \\
\text { and Online Political } \\
\text { Participation scale by } \\
\text { Yang \& DeHart (2016) } \\
\text { and the scale of } \\
\text { integrity (Integrity } \\
\text { Scale) developed by } \\
\text { Schlenker (2008) }\end{array}$ & $\begin{array}{l}\text { Media-savvy refers to the user's } \\
\text { ability to find information on social } \\
\text { media by examining the integrity } \\
\text { and honesty of the media content } \\
\text { collected. }\end{array}$ & .89 \\
\hline $\begin{array}{l}\text { Authentic } \\
\text { sources }\end{array}$ & $\begin{array}{l}\text { The Social Media Use } \\
\text { and Online Political } \\
\text { Participation scale by } \\
\text { Yang \& DeHart (2016) } \\
\text { and the scale of } \\
\text { integrity (Integrity } \\
\text { Scale) developed by } \\
\text { Schlenker (2008) }\end{array}$ & $\begin{array}{l}\text { Authentic sources refer to the } \\
\text { effectiveness of using social media } \\
\text { to find reliable, accurate political } \\
\text { information. }\end{array}$ & .91 \\
\hline $\begin{array}{l}\text { Moral } \\
\text { Creation }\end{array}$ & $\begin{array}{l}\text { The Social Media Use } \\
\text { and Online Political } \\
\text { Participation scale by } \\
\text { Yang \& DeHart (2016) } \\
\text { and the scale of } \\
\text { integrity (Integrity } \\
\text { Scale) developed by } \\
\text { Schlenker (2008) }\end{array}$ & $\begin{array}{l}\text { Moral Creation refers to the skills of } \\
\text { individuals to disseminate } \\
\text { information/ news/ political articles } \\
\text { obtained on mainstream news } \\
\text { portals and that do not have an } \\
\text { element of defamation/ false } \\
\text { information/ cause tension on social } \\
\text { media }\end{array}$ & .89 \\
\hline $\begin{array}{l}\text { Ethical } \\
\text { Actions }\end{array}$ & $\begin{array}{l}\text { The Social Media Use } \\
\text { and Online Political } \\
\text { Participation scale by } \\
\text { Yang \& DeHart (2016) } \\
\text { and the scale of } \\
\text { integrity (Integrity } \\
\text { Scale) developed by } \\
\text { Schlenker (2008) }\end{array}$ & $\begin{array}{l}\text { Ethical Actions refers to an } \\
\text { individual's ability to participate in } \\
\text { politics on social media without } \\
\text { engaging in unethical or unlawful } \\
\text { behaviour such as uploading/ } \\
\text { downloading pornographic videos/ } \\
\text { photographs, inciting the } \\
\text { community to create chaos/ hatred } \\
\text { on social media is a horrific conduct, } \\
\text { etc. }\end{array}$ & .91 \\
\hline
\end{tabular}

\section{Data Analysis}

Data were examined using descriptive statistics to describe the respondent profile and Exploratory Factor Analysis (EFA) using IBM SPSS 21.0 software. EFA analysis is an important foundation for solidifying construct development (Schumacker \& Lomax, 2010). The main uses of EFAs are to reduce the number of items and detect the structure of relationships between items that make up construct dimensions (Hair et al., 2010). $\mathrm{n}$ this study, principal component analysis with varimax rotation was used to determine the number of components. 
Confirmatory Factor Analysis (CFA) was performed using SPSS AMOS 21.0 software. The CFA aims to determine the number of items included in a construct in parallel with what is stated in theory (Byrne, 2010). The goodness of fit of the CFA model is determined based on a combination of at least one Absolute Fit Indices and the Incremental Fit Indices (Hu \& Bentler, 1999; Hair et al., 2010) and parsimony Fit Indices (Hair et al., 2010). The goodness of fit is used to determine whether the tested model should be accepted or rejected. However, no specific rule can determine what fit index should be reported for a model (Hooper, Coughlan \& Mullen; 2008, Hair et al., 2010). The use of three or more matching indices is sufficient to prove that a model achieves goodness of fit without reporting all existing goodness of fit indices (Hair et al., 2010).

\section{Result}

The demographic profiles of the respondents are as in Table 2, with a total sample of the study is 388 respondents. The gender distribution of the study respondents was 42.5 per cent female and 57.5 per cent, male. The results also showed that the respondents aged between 21 to 23 years were 213 or 54.9 per cent. More than 85 per cent of respondents are married. Most respondents had their education at the college or higher education level. 2.6 per cent were STPM, 3.6 per cent were Matriculation, 2.6 per cent were pre-diploma, and 59.8 per cent were diploma holders, while 32 per cent had a Bachelor's Degree. In addition, 49.2 per cent of respondents use social media more than ten times a day, and 29.6 per cent of respondents use it to update social media accounts for 1-30 minutes.

Table 2 : Respondent Demographics Profile

\begin{tabular}{lll}
\hline Profile & Frequency & Percentage (\%) \\
\hline Gender & & \\
Male & 165 & 42.5 \\
Female & 223 & 57.5 \\
Age & & \\
$18-20$ & 37 & 9.5 \\
$21-23$ & 213 & 54.9 \\
$24-26$ & 88 & 22.7 \\
$27-29$ & 37 & 9.5 \\
$30-40$ & 13 & 3.4 \\
Status & & \\
Single & & 87.1 \\
Married & 338 & 9.8 \\
Others & 38 & 3.1 \\
& 12 & \\
Religion & & 74.7 \\
Islam & & 10.1 \\
Christian & & 9.3 \\
Buddha & 290 & 4.4 \\
Hindu & 39 & \\
\hline
\end{tabular}




\begin{tabular}{|c|c|c|}
\hline Others & 6 & 1.5 \\
\hline \multicolumn{3}{|l|}{ Race } \\
\hline Malay & 286 & 73.7 \\
\hline Chinese & 66 & 17.0 \\
\hline Indian & 19 & 4.9 \\
\hline Others & 17 & 4.4 \\
\hline \multicolumn{3}{|l|}{ Education level } \\
\hline STPM & 10 & 2.6 \\
\hline Matriculation & 14 & 3.6 \\
\hline Pre-Diploma & 10 & 2.6 \\
\hline Diploma & 232 & 59.8 \\
\hline Degree & 124 & 32.0 \\
\hline \multicolumn{3}{|c|}{ Higher education institutions } \\
\hline UiTM & 136 & 35.1 \\
\hline UTeM & 99 & 25.5 \\
\hline MMU & 100 & 25.8 \\
\hline KUIM & 53 & 13.7 \\
\hline \multicolumn{3}{|c|}{ How often do you use social media daily? } \\
\hline 1-2 times & 24 & 6.2 \\
\hline 3-5 times & 80 & 20.6 \\
\hline 6-10 times & 93 & 24.0 \\
\hline$>10$ times & 191 & 49.2 \\
\hline \multicolumn{3}{|c|}{ Time spent updating social media accounts? } \\
\hline 1-30 minutes & 115 & 29.6 \\
\hline 31 minutes -1 hour & 98 & 25.3 \\
\hline $1-2$ hours & 85 & 21.9 \\
\hline$>3$ hours & 90 & 23.2 \\
\hline
\end{tabular}

\section{Exploratory Factor Analysis}

The Measurement Scale of Political Participation Integrity in social media tested consist of four constructs, namely media proficiency, authentic sources, moral creation, and ethical action, which all contained 29 items. The Kaiser-Meyer Olkin Measure of Sampling Adequacy $(\mathrm{KMO})=0.942$ is greater than 0.6 , and the sampling is adequate (Hair et al., 2010; Pallant, 2007). While the value of Bartlett's Test was statistically significant $(p<.05)$. This shows that the items employed in this study's Exploratory Factor Analysis have a strong inter-correlation with one another. Table 3 displays the findings of KMO and Bartlett's test. 
Table 3 : KMO and Bartlett's Test

\begin{tabular}{|c|c|c|c|}
\hline Kaiser-Mey & r-Olkin Mea & sure of Sampling Ade & .942 \\
\hline $\begin{array}{l}\text { Bartlett's } \\
\text { Sphericity }\end{array}$ & Test of & Approx. Chi-Square & 9775.983 \\
\hline & & $\mathrm{df}$ & 528 \\
\hline & & sig. & .000 \\
\hline
\end{tabular}

Items with a loading factor less than 0.50, according to Hair et al. (2010), should be discarded. All items in this study were accepted due to a factor loading of more than 0.50, i.e. between.56 and.91). Researchers used Average Variance Extracted (AVE) and Construct Reliability (CR) to test convergent validity. According to Hair et al. (2010), the AVE value must be greater than 0.5 and the CR greater than 0.7. Based on AVE values for Media-savvy, authentic sources, moral creation, and ethical action, these four constructs exceeded 0.5. The reliability values for the four latent variables (constructs) ranged from 0.877 to 0.953 , which is greater than the value of 0.70 , indicating Cronbach's Alpha is in good condition. Discriminant validity is to measure one construct with another construct and should not have a high correlation. Byren (2010) suggested a value of $r=0.90$ or more indicates that the variable has a high correlation. Since the correlation findings in Table 4 show values between 0.712 to 0.863 , there is no high correlation problem (multicollinearity).

Table 4 : Average Variance Extracted, Composite Reliability, Reliability and Correlation

\begin{tabular}{llllllll}
\hline $\begin{array}{l}\text { Latent variable } \\
\text { (Construct) }\end{array}$ & CR & AVE & $\alpha$ & $\mathbf{1}$ & $\mathbf{2}$ & $\mathbf{3}$ & $\mathbf{4}$ \\
\hline (1) Media-savvy & 0.949 & 0.702 & 0.940 & $\mathbf{0 . 8 3 8}$ & & & \\
(2) Authentic sources & 0.901 & 0.565 & 0.901 & 0.800 & $\mathbf{0 . 7 5 2}$ & & \\
(3) Moral Creation & 0.877 & 0.507 & 0.886 & 0.772 & 0.874 & $\mathbf{0 . 7 1 2}$ & \\
(4) Ethical Actions & 0.953 & 0.745 & 0.954 & 0.185 & 0.345 & 0.333 & $\mathbf{0 . 8 6 3}$ \\
\hline
\end{tabular}

Note: AVE $=$ Average Variance Extracted, $C R=$ composite reliability, $\alpha=$ Alpha Cronbach's 
Table 5: Factor loading of each item

\begin{tabular}{|c|c|c|c|}
\hline MM1 & 回 & Media-savvy & $.568 * * *$ \\
\hline MM2 & 回 & Media-savvy & $.849 * * *$ \\
\hline MM3 & 回 & Media-savvy & $.869 * * *$ \\
\hline MM4 & 回 & Media-savvy & $.855^{* * *}$ \\
\hline MM5 & 回 & Media-savvy & $.921 * * *$ \\
\hline MM6 & 回 & Media-savvy & $.851 * * *$ \\
\hline MM7 & 㘣 & Media-savvy & $.892 * * *$ \\
\hline MM8 & 㘣 & Media-savvy & $.849 * * *$ \\
\hline SS1 & 㘣 & Authentic sources & $.754 * * *$ \\
\hline SS2 & 㘣 & Authentic sources & $.748 * * *$ \\
\hline SS3 & 㘣 & Authentic sources & $.786 * * *$ \\
\hline SS4 & 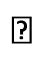 & Authentic sources & $.787 * * *$ \\
\hline SS5 & 回 & Authentic sources & $.789 * * *$ \\
\hline SS6 & 回 & Authentic sources & $.754 * * *$ \\
\hline SS7 & 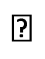 & Authentic sources & $.749 * * *$ \\
\hline PM1 & 回 & Moral Creation & $.761 * * *$ \\
\hline PM2 & 回 & Moral Creation & $.745^{* * *}$ \\
\hline PM3 & 㘣 & Moral Creation & $.746 * * *$ \\
\hline PM4 & 回 & Moral Creation & $.782 * * *$ \\
\hline PM5 & 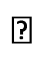 & Moral Creation & $.633 * * *$ \\
\hline PM6 & 回 & Moral Creation & $.715^{* * *}$ \\
\hline PM7 & 回 & Moral Creation & $.627^{* * *}$ \\
\hline TE1 & 㘣 & Ethical Actions & $.792 * * *$ \\
\hline TE2 & 㘣 & Ethical Actions & $.898 * * *$ \\
\hline TE3 & 㘣 & Ethical Actions & $.914 * * *$ \\
\hline TE4 & 㘣 & Ethical Actions & $.902 * * *$ \\
\hline TE5 & 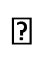 & Ethical Actions & $.887^{* * *}$ \\
\hline TE6 & 回 & Ethical Actions & $.840 * * *$ \\
\hline TE7 & 回 & Ethical Actions & $.803 * * *$ \\
\hline
\end{tabular}

*** Standardized Regression Weights is significant at .001 level (2-tailed)

All factors loading were significant at the level of 0.001 and exceeded 0.5 for all indicators. In addition, high standardized regression values (0.568 to 0.921$)$ indicate that all measured variables can significantly represent their latent variables (constructs).

\section{Confirmatory Factor Analysis}

The model specification involved 29 items, namely eight items for media-savvy and seven items each for authentic sources, moral creation, and ethical action. However, this model needs to be modified to represent the sample data or actual data better. The modification index (MI) is a guide for modifications. As a result, items with high $\mathrm{MI}$ and high correlation between the two items need to modify. Based on Hair et al. (2014), if the correlation is high between two items, it can be combined to obtain a matching model. Whereas items are not theoretically supported and correlated, the model needs to modify by removing items with a lower factor loading between the two items (Hair et al., 2014).

After modification, the second analysis of the model improved. The measurement model in Table 6 attained goodness of fit with eight indicators, namely ( $\chi 2$, CMINDF, RMSEA, 
GFI, IFI, TLI, CFI and PGFI). CMINDF for this measurement model is 2.867. According to Marsh and Hau (1996), the CMINDF value of less than five shows that the CFA model is good. Furthermore, the RMSEA value is 0.069 , which is lower than .08, as suggested by Kline (2010). The coefficients index in Table 6 and Figure 1 are all greater than 0.90, indicate that the model achieved goodness of fit (Byrne, 2010) and PGFI values greater than 0.5 (0.692), which also show acceptable model fit indices (Hair et al., 2010). Figure 1 shows the CFA Model for this study.

Figure 1: CFA Model of Political Participation Integrity

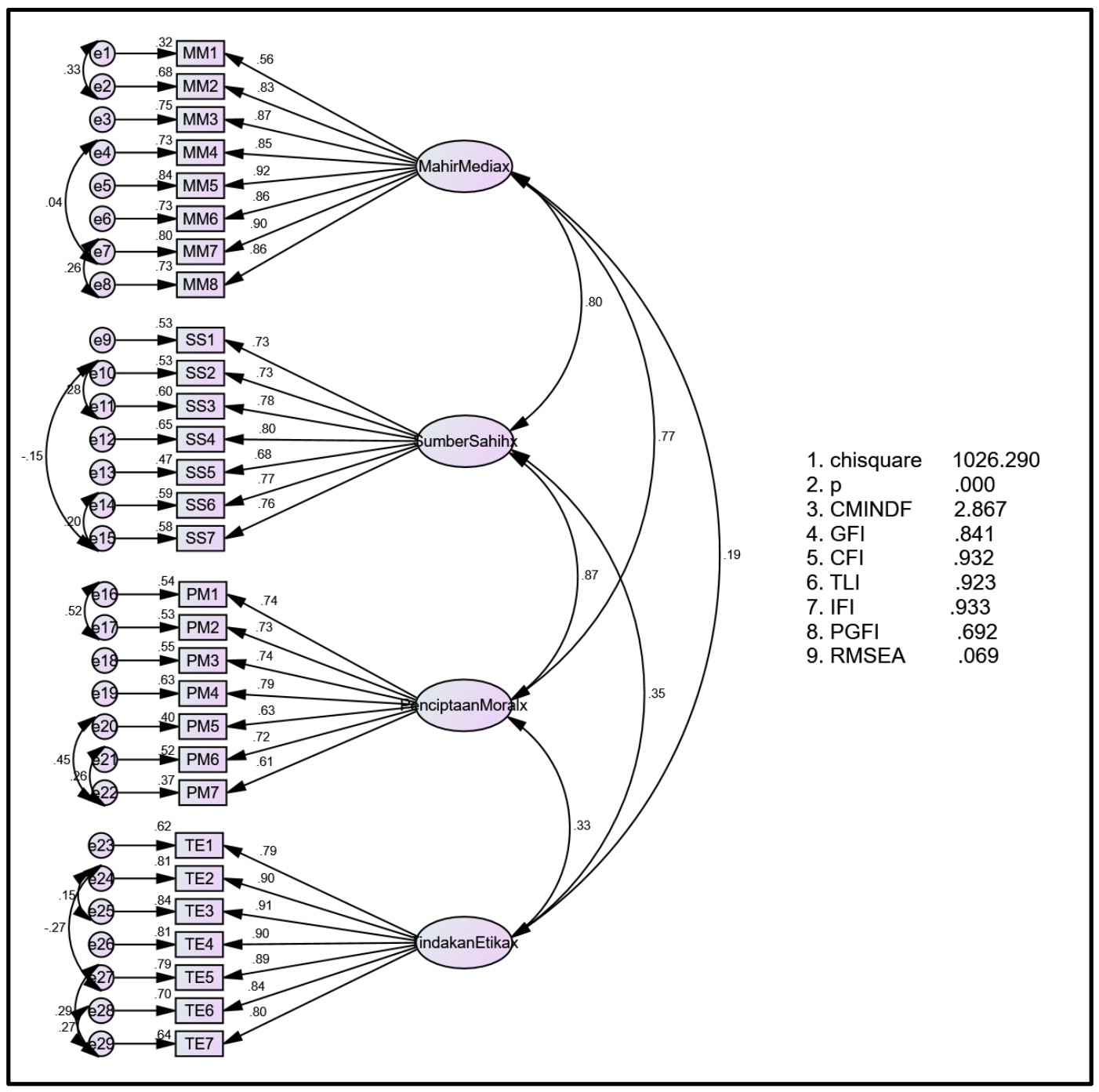

Table 6 : Confirmatory Factor Analysis (CFA)

\begin{tabular}{lllllllll}
\hline Description & $\chi^{2}$ & CMINDF & RMSEA & GFI & IFI & TLI & CFI & PGFI \\
\hline Model CFA & 1026.290 & 2.867 & 0.069 & 0.841 & 0.933 & 0.923 & 0.932 & 0.692 \\
\hline
\end{tabular}

\section{Discussion}

The findings indicate that the multi-dimensional model of the political participation integrity scale has achieved good matching accuracy and achieved convergent validity based on significant relationships of variables. This scale also reached discriminant validity and predictive validity that supports psychometric characteristics of the Malay version. The 
confirmatory factor analysis (CFA) in the political participation integrity model also reveals that media-savvy, authentic sources, moral creation, and ethical actions have tested thoroughly to represent their respective constructs.

\section{Conclusion}

The importance of translating into Malay is to allow researchers to better comprehend and measure the level of political participation among Malaysians. Because the measuring of political involvement integrity in social media is inadequately established in Malaysia, this must be implemented. The main focus of this study was to identify the psychometric features, i.e. aspects of validity and reliability of political participation integrity scale in social media adapted from social media usage scale and online political participation developed by Yang \& DeHart (2016) and Integrity scale developed by Schlenker (2008). The importance of translating into Malay allows researchers to better comprehend and measure the level of political participation integrity among Malaysians. This scale is necessary because Malaysia's measurement of political participation integrity in social media is inadequate. This study highly contributes to the development of Political Participation Integrity Scale that little study mention previously. Past study, highly focused on political participation but little study eager to develop political participation scale, especially with new construct known as integrity. This study reported that media-savvy, authentic sources, moral creation, and ethical actions are highly contributes to the political participation integrity scale. In addition, political participation questionnaire published from previous study highly tested among adult voters but not specifically verified among young voters. The new context tested in this study highly contributed to the young voters in political participation integrity.

\section{Corresponding Author}

Dr. Mohd Sufiean Hassan, Faculty of Communication and Media Studies, Universiti Teknologi MARA (UiTM), Melaka Branch, Km 26. Jalan Lendu, 78000 Alor Gajah, Melaka, Malaysia. Email: mohdsufiean@uitm.edu.my

\section{Acknowledgement}

The authors would like to thank the Ministry of Higher Education, Universiti Teknologi MARA, Melaka Branch and Kolej Universiti Islam Melaka for the funding received under the Fundamental Research Grant Scheme (FRGS), Malaysia (FRGS/1/2020/SSO/KUIM/03/1) to support this study.

\section{References}

Al-Kandari, A., \& Hasanen, M. (2012). The impact of the Internet on political attitudes in Kuwait and Egypt. Telematics and Informatics, 29(3), 245-253.

Anduiza, E., Gallego, A., \& Jorba, L. (2012). Internet use and the political knowledge gap in Spain. Revista Internacional de Sociología, 70, 129-151.

Babbie, E. (2013). The Practice of Social Research (13th ed.). Wadsworth, Cengage Learning.

Bekafigo, M. A., \& McBride, A. (2013). Who tweets about politics? political participation of twitter users during the 2011 Gubernatorial Elections. Social Science Computer Review, 31(5), 625-643.

Berger, J., \& Milkman, K. L. (2012). What makes online content viral? Journal of Marketing Research, 49(2), 192-205.

Chan-Olmsted, S. M., Moonhee, C., \& Sangwon, L. (2013). User perceptions of social media: a 
comparative study of perceived characteristics and user profiles by social media. Online Journal of Communication \& Media Technologies, 3(4), 149-178.

Dunne, Á., Lawlor, M., \& Rowley, J. (2010). Young people's use of online social networking sites $-a$ uses and gratifications perspective. Journal of Research in Interactive Marketing, 4(1), 46-58.

Eckstein, K., Noack, P., \& Gniewosz, B. (2013). Predictors of intentions to participate in politics and actual political behaviors in young adulthood. International Journal of Behavioral Development, 37(5), 428-435.

Febriansyah, M., \& Ismail, M., T. (2013). Partisipasi anak muda dalam politik baru di Malaysia. In Simposium Kebudayaan Indonesia Malaysia (SKIM). Bandung: Universitas Padjajaran, Indonesia.

Ferrari, E. (2018). Fake accounts, real activism: Political faking and user-generated satire as activist intervention. New Media and Society, 20(6), 2208-2223.

Gil de Zúñiga, H., Jung, N., \& Valenzuela, S. (2012). Social media use for news and individuals' social capital, civic engagement and political participation. Journal of ComputerMediated Communication, 17(3), 319-336.

Gustafsson, N. (2012). The subtle nature of Facebook politics: Swedish social network site users and political participation. New Media \& Society, 14(7), 1111-1127.

Hair, J. F., Black, W. C., Babin, B. J., \& Anderson, R. E. (2014). Multivariate Data Analysis. Pearson Education Limited.

Hashim, M. A., Mahpuz, M., Khan, N. A., \& Daud, N. M. (2012). Investigating the use of Social Media Among the Young Urban Middle Class in Malaysian politics, and its potential role in changing the Nation's political landscape. Advances in Natural and Applied Sciences, 6(8), 1245-1251.

Herman, B. D. (2011). New media law and policy. New Media \& Society, 13(2), 350-356.

Kahne, J., \& Bowyer, B. (2018). The political significance of social media activity and social networks. Political Communication, 00(00), 1-24.

Kümpel, A. S., Karnowski, V., \& Keyling, T. (2015). News Sharing in Social Media: A Review of Current Research on News Sharing Users, Content, and Networks. Social Media + Society, 1(2), 1-14.

Lee, C. S., \& Ma, L. (2012). News sharing in social media: The effect of gratifications and prior experience. Computers in Human Behavior, 28(2), 331-339.

Leong, P. (2015). Political communication in Malaysia: a study on the use of new media in politics. JeDEM, 7(1), 46-71.

Lunnay, B., Borlagdan, J., McNaughton, D., \& Ward, P. (2015). Ethical use of social media to facilitate qualitative research. Qualitative Health Research, 25(1), 99-109.

Marsh, D. (2008). New forms of political participation: searching for expert citizens and everyday makers. B.J.Pol.S, 38(1), 247-272. https://doi.org/10.1017/S0007123408000136

Mohamad, B., Abdu, S. D., \& Halim, H. (2018). Youth offline political participation: Trends and role of social media. Jurnal Komunikasi, 34(3), 192-207.

Razali, M., Boyman, S. N., Hussin, N. I., \& Nor, W. M. W. A. (2016). Penglibatan politik belia: Satu analisis penyertaan konvensional di Malaysia. Jurnal Perspektif, 2(8), 70-78.

Azizuddin, M. S. (2014). The social media election in Malaysia: The 13th general election in 2013. Kajian Malaysia, 32(March 2008), 123-147.

Fauzi, M. H., \& Naim, M. K. C. N. (2012). Tinjauan kepentingan pembangunan modal insan di Malaysia (Review on the importance of human capital development in Malaysia). Jurnal 
Al-Tamaddun, 7(1), 75-89.

Hamdan, M. H. A. (2015). Peranan media massa memartabatkan integriti nasional. Jurnal Komunikasi Borneo, 2, 57-74.

Hassan, M. S., Allam, S. N., Azni, M. Z., \& Khamis, M. H. (2013). Social media and political participation among young people. Jurnal Sains Sosial, 1(1), 95-114.

Muntaen, A. (2015). The impact of Social Media use of political participation (Issue August). Aarhus University.

Norni, M. (2013). 13.3 million M'sians are Facebook users. Borneo Post. http://www.theborneopost.com/2013/06/16/13-3-million-msians-are-facebook-users/

Norris, P. (2000). The worldwide digital divide: Information poverty, the Internet and development. In Annual Meeting of the Political Studies Association of the UK, London School of Economics and Political Science.

Picone, I., De Wolf, R., \& Robijt, S. (2016). Who shares what with whom and why?: news sharing profiles amongst flemish news users. Digital Journalism, 4(7), 921-932.

Rogstad, J., \& Vestel, V. (2011). The art of articulation: political engagement and social movements in the making among young adults in multicultural settings in Norway. Social Movement Studies, 10(3), 243-264.

Salman, A., Ibrahim, F., Abdullah, M. Y., Mustaffa, N., \& Mahbob, M. H. (2011). The impact of new media on traditional mainstream mass media. Innovation Journal, 16(3), 2-11.

Schlenker, B. R. (2008). Integrity and character: implications of principled and expedient ethical ideologies. Journal of Social and Clinical Psychology, 27(10), 1078-1125.

Schlenker, B. R., Miller, M. L., \& Johnson, R. M. (2009). Moral identity, integrity, and personal responsibility. In Personality, identity, and character: Explorations in moral psychology (pp. 316-340). Cambridge University Press.

Shaheen, M. (2008). Use of social networks and information seeking behavior of students during political crises in Pakistan: A case study. The International Information Library Review, 40(3), 142-147.

Subramaniam, B. (2015). On the social media circuit. The Star Online. http://www.thestar.com.my/News/Education/2014/01/05/On-the-social-mediacircuit/

Theocharis, Y., \& Quintelier, E. (2014). Stimulating citizenship or expanding entertainment? The effect of Facebook on adolescent participation. New Media \& Society, 1, 1-20.

University, S. H. (2014). How to: Use Social Media for Recruiting. Sheffield Hallam University. http://mashable.com/2011/06/11/social-media-recruiting/

Valenzuela, S. (2013). Unpacking the use of social media for protest behavior: the roles of information, opinion expression, and activism. American Behavioral Scientist, 57(7), 920-942.

Valenzuela, S., Arriagada, A., \& Scherman, A. (2012). The social media basis of youth protest behavior: the case of Chile. Journal of Communication, 62(2), 299-314.

Wellman, B., \& Haase, A. (2001). Does the internet increase, decrease, or supplement social capital? Social networks, participation, and community commitment. American Behavioral Scientist, 45(3), 436-455.

Yang, H. C., "Chris," \& DeHart, J. L. (2016). Social media use and online political participation among college students during the US election 2012. Social Media + Society, 1(1), 1-18.

Yoo, S. W., \& Gil de Zuniga, H. (2014). Connecting blog, Twitter and Facebook use with gaps in knowledge and participation. Communication and Society, 27(4), 33-48.

Zhang, W., \& Chia, S. C. (2006). The effects of mass media use and social capital on civic and 
INTERNATIONAL JOURNAL OF ACADEMIC RESEARCH IN BUSINESS AND SOCIAL SCIENCES Vol. 11, No. 8, 2021, E-ISSN: 2222-6990 @ 2021 HRMARS

political participation. Communication Studies, 57(3), 277-297. 